\title{
THE RIGHT OF PRIVATE DEFENSE AGAINST NON- ACCOUNTABLE OFFENDERS AND IN DEFENSE OF THE CHASTITY OF WOMEN UNDER ISLAMIC LAW
}

\author{
Khalid Owaydhah* \\ Mohamad Ismail bin Mohamad Yunus***
}

\begin{abstract}
The right of self-defense under Islamic law (Shariah) distinguishes between two concepts: private and public defense. In this article, legal and practical manifestations of the contemporary legal issue of private defense in the case of physical assaults made by non-accountable (mukallaf) offenders, such as minors and insane persons are focused. Aside from that, this article also analyses the use of private defense to protect the chastity of a woman. The four conditions to exercise the right of private defense are highlighted. In order to explore the effects of private defense, the significance of keeping the lawful measures and exceeding the right of self-defense are also discussed.
\end{abstract}

Keywords: private defense, non-accountable, minor, insane person, woman, maqasid al-shariah

\section{HAK PERTAHANAN DIRI PENSENDIRIAN TERHADAP PESALAH BUKAN MUKALLAF DAN DALAM MEMPERTAHANKAN KEHORMATAN WANITA DALAM UNDANG-UNDANG ISLAM}

Hak pembelaan diri di bawah undang-undang Islam (Syariah) membezakan antara dua konsep: pertahanan diri persendirian dan awam. Dalam makalah ini, manifestasi undang-undang dari segi praktikaliti mengenai isu undang-undang kontemporari pertahanan diri persendirian dalam kes serangan fizikal yang dibuat oleh kanak-kanak dan orang gila difokuskan. Selain daripada itu, makalah ini mengkaji

Ph.D. Candidate, Flinders Law School, Flinders University, Australia. Assistant Professor, the Department of Legal Practice, Ahmad Ibrahim Kulliyyah of Laws, International Islamic University Malaysia. 
mengenai pertahanan diri persendirian untuk melindungi maruah seorang wanita. Empat syarat utama dalam melaksanakan hak pertahanan diri persendirian juga diketengahkan. Untuk mengkaji kesan pertahanan diri pensendirian, kepentingan mengekalkan batasan hak yang sah, serta batasan yang melampaui hak pembelaan diri persendirian juga dibincangkan.

Kata kunci: pertahanan diri pensendirian, mukallaf, kanak-kanak, orang gila, wanita, objektif undang-undang Islam.

\section{INTRODUCTION}

Under the principle of Maqasid al-Shariah (Objectives of Islamic Law) and the modern secular law, the right of private defense is absolutely necessary for the protection of one's person, habitation or property against the assailant who manifestly intends and endeavours to take them away. No doubt, it is the primary duty of the state to protect the life and property of its individual, but no state, no matter how large its recourse might be, can depute a policeman, to watch the activities of each and every individual and protect him against the act of criminals. There may be situations where the help of the state authorities cannot be obtained in order to prevent an unlawful aggression either because no time is left to ask for such help or for any other reason. Therefore, in order to meet such exigencies, the Shariah has given such right of private defense to every individual Muslim or non-Muslim. ${ }^{1}$

However, due to legal and medical incapacity, a minor and an insane person are exempted from any criminal liability. According to Abu Zaid al- Qayrawani, a child will not be punished for a crime committed, due to the lack of legal capacity as a minor, i.e. children of all ages until they reach the age of puberty. ${ }^{2}$ Similarly, an insane person also lacks legal capacity as he does not have the ability to appreciate the nature of his acts. Therefore, no punishment can be imposed upon him due to such deficiency until and unless he becomes a sane person. ${ }^{3}$

1 Mohamad Ismail Mohamad Yunus. 2014. A Commentary on Criminal Law and Evidence. Kuala Lumpur. Marsden Law Book. pp. 489-523.

2 Ar-Risalah. (nd). Beirut. Darul Fikr, 121.

3 Abdur Rahman I.Doi. 1984. Shariah: The Islamic Law. Kuala Lumpur. A.S. Noordeen, 227; Mohamad Ismail Mohamad Yunus, 'The Right of Self 
This raises an important issue, i.e. whether the right of private defense can be exercised upon these two categories of persons who lack legal capacity. Since they cannot be held accountable under the Shariah for committing a criminal act, would reacting in defense to their assault results in an unjustifiable act on the part of the victim? The aim of this article is to address the issue raised from the exercise of the right of self defense when it involves assailants who lack legal capacity, in that they are minors or insane persons. These two issues will be dealt with in the first part of the article.

Subsequently, the second part of the article also examines the extent a person could act when defending the honour and chastity of a woman. This may involve the act of defending a woman by another person or by the woman herself. This discussion is related to the discussion on private defense due to the possibility of the victim exceeding the limits permitted for acts of self-defense.

\section{THE MEANING OF ACCOUNTABILITY IN ISLAM (MUKALLAF)}

An accountable person (mukallaf) is a person who has fulfilled the three basic requirements of being a mukallaf. He must be a person who is 'aqil (sound mind), baligh (reached the age of puberty) and he must also be able to exercise consent of his own free will. ${ }^{4}$ Puberty happens when one reaches the age of fifteen (15) lunar years. Meanwhile, a sane person is "healthy in mind and not mad". 5 The third condition is the ability to act of their own free will and that any criminal acts was done voluntarily. The general rule in relation to persons who lack either one of these conditions is that they cannot be held accountable for any criminal acts committed by them. Nevertheless, for the purpose of this article, concentration is made only to the conditions of puberty and insanity.

The abovementioned ruling is based on the Hadith of the Messenger of Allah (pbuh), who said: "The pen has been lifted from [writing the

Defense of A Person: A Comparative Legal Alignment' (2015) 11 Journal of Islamic Law Review. 118-119.

4 Abdul Qader 'Oudah. 1999. Criminal Law of Islam. (Trans.)New Deelhi. Kitab Bhavan. p. 90.

5 AS Hornby. Oxford Advanced Learner's Dictionary of Current English. Oxford. 
deeds of] three: the one who is asleep until he awakens, the young child until he becomes pubescent, and the crazy person until becomes sane." (Related by Abu Dawud). ${ }^{6}$

The next part continues to explain whether a victim can exercise his right of private defense against an assailant who is either a child or an insane person.

\section{PRIVATE DEFENSE AGAINST VIOLENCE COMMITTED BY MINORS AND INSANE PERSONS}

In elaborating on the issue of private defense, it is pertinent to explore the practical manifestations of exercising this sort of defense by a person in cases of attack made by minors and the insane. Unlike sane adult individuals, minors and insane individuals are incapable of committing crimes as the element of guilty mind (mens rea) cannot easily be established.

As far as Islamic law is concerned, a rather contentious view was put forward by Hanafi jurists, with the exception of Imam Abu Yusuf, wherein they opine that the key requirement for the exercise of selfdefense lies in the contention that the attacker must be criminally liable and the attacker's physical act (actus reus) must constitute a criminally punishable offence under the provisions of law. ${ }^{7}$ This notwithstanding, in a case when the victim kills a minor or an insane individual in the course of exercising his or her right of self-defense, it is impossible to make the victim liable for retaliation (qisas) because, under the aforementioned circumstances, his or her liability is diminished. However, since the offender is a minor or an insane person and cannot accept criminal responsibility, therefore, this view subscribes that the victim can be made liable to pay blood money (diyat) to the offender's heirs. The key rationale underlying the diminished criminal liability of the victim for killing an assailant in self-defense stems from the fact that the acts of a minor or an insane individual cannot be considered crimes and, therefore, the victim acts under the necessity of defending his rights. However, the

\footnotetext{
6 http://www.alsunna.org/Islamic-Beliefs/accountablemukallaf.html/retrieved on 18 December 2018.

7 T Wasti, 2008. The Application of Islamic Criminal Law in Pakistan: Sharia in Practice (Brill), 58.
} 
necessity under which the victim confronts a minor or an insane individual does not influence the former's civil liability. To that end, the diminished liability of the victim - the obligation to redress damages serves as a compromise. This situation resembles the case where an individual is assaulted by a dangerous animal and kills the animal to save his life. To the similar effect, in a case of an imminent and brutal attack by a minor or an insane person, the killing of such an assailant is endured and the victim is subjected to compensation. ${ }^{8}$

In contrast to the Hanafi jurists, Imam Abu Yusuf, as well as the majority of Islamic jurists, ${ }^{9}$ contends that it is not necessary that the offender be criminally liable. Here, the act of a minor or an insane individual may fulfil actus reus of a criminally punishable offence, whereas an insane assailant may not be criminally liable because the requirement of mens rea is absent. Meanwhile, the minor assailant could not be liable for lack of legal capacity to receive criminal responsibility, although he may have the ability to form the mens rea. Therefore, if a victim kills an insane or minor assailant as an act of self-defense, then he cannot be liable for any wrongful act and neither does he have to pay any sort of compensation or diyat to the heirs of the assailant. ${ }^{10}$

The majority opinion on the exercise of, the right of private defense against a minor or insane individual under Islamic law resembles that taken by the majority of civilised countries. To be more precise, while addressing the right of private defense, the criminal law of Islam tends to expressly provide that an individual is entitled to exercise his right to self-defense against a minor or insane individual in the same manner as against a legally competent person. This notwithstanding, the actual separation of the right to self-defense against a minor or insane individual proves the existence of specific differences between self-defense against a person who is legally competent person and one who is not. This is different from the position taken by the jurists from the Hanafi school which provides that the key difference lies in the fact that the death of a minor or an insane individual in the course of exercising the right of private defense obligates the victim to pay blood money (diyat), whereas

\section{Ibid, 60.}

Ibid, 63.

10 Sayid Sikandar Shah Haneef. 2000. Homicide in Islam. Legal Structure and the Evidentiary Requirements. A.S. Noordeen. p. 134. 
the death of a legally competent individual under the same circumstances does not entail any obligation to redress.

The problem of self-defense against a minor or an insane individual is also intertwined with another issue of Islamic criminal law- the issue of evidence. The general rule of evidence states that it is incumbent on the plaintiff to substantiate his claim with evidence and he is entitled to do so by the testimony of witnesses or by the admission of the defendant. ${ }^{11}$ As far as the issue of self-defense against a minor or an insane individual is concerned, the court is predisposed not to admit evidence because of a minor's inconsistency. In other words, if a minor, who has allegedly attacked the defendant, decides to testify, the court may not admit his evidence. Therefore, the burden of proof in a case where the victim acted in self-defense against a minor or an insane individual, is imposed upon the victim. Hence, it follows that the victim who has exercised his right to self-defense against a minor or an insane individual has a heavier burden whereby he is required to prove his innocence and avoid criminal liability if compared to a victim who has performed his right of self-defense against a legally competent assailant, who does not need to discharge this burden of proof.

However, if the victim exceeds the degree of permissible defense by applying excessive force against a minor or an insane individual, he needs to be prove, albeit through circumstantial evidence (al-qarinah) that the excessive force was necessary in stopping or preventing criminal conduct against him. This is because a minor or an insane person who commits an offence carries no burden of responsibility for the harmful outcomes due to the absence of mens rea or because actus reus cannot be imputed to such an offender. As to the problem with actus reus, almost any conduct of a minor or an insane individual loses its unlawful character (actus reus). Therefore, it is sometimes difficult to justify the application of guilty mind (mens rea) in self-defense against a minor or an insane individual when the assailant's act contains all the elements of

11 R. Peters, 2005. Crime and Punishment in Islamic Law: Theory and Practice from the Sixteenth to the Twenty-First Century (Cambridge University Press), 12; T Wasti, 2008. The Application of Islamic Criminal Law in Pakistan: Sharia in Practice (Brill), 58. 
a criminal offence but cannot be imputed to the person who has committed it. ${ }^{12}$

The absence of mens rea complicates the process of invoking and justifying the defense of self-defense under Islamic criminal law. According to Hanafi jurists, there are three mandatory requirements for the application of legal punishment. First, it is necessary that the offender has the actual power to commit or not to commit the act (qudra). Second, it is essential that the offender is conscious that the act he has committed is an offence ( $\mathrm{ilm}$ ). Third, it is necessary that the offender has acted with intent to commit the offence (qasd). All the above-captioned elements may be synthesised as a framework for a theory of mens rea in respect of offences punishable with retaliation (qisas) and prescribed (hadd) offences. However, these elements can also be applied to instances of self-defense against a minor or an insane individual. In this context, minors and insane individuals cannot be held liable for their offences because they are unable to accept legal responsibility and therefore cannot be held accountable for their actions, although it may be illegal. Aside from the authority quoted above, Sayyidna Ali r.a once said to Sayyidna Umar r.a: "Do you know that no deed good or evil are recorded (for the following) and they are not responsible for what they do: (1). A minor till he grows to the age of puberty (2). An insane person till he becomes sane. ${ }^{13}$

Thus under the Islamic criminal law, the criminal liability of a minor and an insane assailants is exempted due to insufficient degree or maturity or lack intellectual capacity to understand fully the implications of their conducts. Minority ends with physical puberty. Insanity ends as a result of healing (treatment). All these circumstances make it possible to conclude that self-defense against a minor or an insane individual is a special and specific type of private defense compared to the standards and principles of private-defense required against normal legal competent individuals. $^{14}$

12 MC Bassiouni, 2008. International Criminal Law. Volume 2 Multilateral and Bilateral Enforcement Mechanisms (Brill), 132.

13 Al-Bukhari, cited in Abdur Rahman I.Doi. 1984. Shariah: The Islamic Law. Kuala Lumpur. A.S. Noordeen, 226.

14 M Lippman, 1988. Islamic Criminal Law and Procedure , 56; MC Bassiouni, 2008. International Criminal Law, Volume 2 Multilateral and Bilateral Enforcement Mechanisms (Brill), 132. 
The next part of the article proceeds to discuss the position of selfdefense for women whose honour or dignity is being attacked by an assailant. How far can a person defending them or they themselves can rely on the defense of self-defense in protecting their chastity.

\section{THE DEFENSE OF THE CHASTITY OF A WOMAN UNDER SHARIAH}

The defense of the chastity of a woman is another type of private defense under Shariah. However, some schools of Muslim jurists do not discern between types of private defense such as the defense of the body, the chastity of a woman and the defense of property, but places emphasis upon the assailant's intent to cause death or serious bodily injury irrespective of other factors. ${ }^{15}$ Nevertheless, the defense of the chastity of a woman still constitutes a specific type of private defense that can be discerned and analysed separately from other types of private defense. Moreover, some Muslim jurists are prone to believe that the defense of the chastity of a woman is not simply a right but a duty under the Shariah. Specifically speaking, based on the concept of Maqasid alShariah, many Muslim jurists opined that every Muslim has an obligation to defend the chastity of his family or the family of any other Muslim. This obligation is, to a considerable extent, dictated by the prohibition of adultery, fornication or other indecent sexual acts. If the aforesaid indecent conduct happens, the person concerned or the woman herself, ought to invoke the defense of private defense without causing the death of the assailant, if possible. Such defense will be viewed as a justificatory or excusatory act because Islam and Shariah dictate the duty to defend chastity. ${ }^{16}$

In elaborating upon the defense of the chastity of a woman further, it needs to be pointed out that in case a Muslim man finds his wife in a compromising situation with a stranger, (or if the woman herself is in that situation), it is incumbent on him to apply minimum possible force to

15 J.N Anderson. 2000. Islamic Law in the Modern World (World Assembly of Muslim Youth), 108.

16 Mohamad Ismail Mohamad Yunus, 'The Exercise of Self Defense to Cause Death; A Legal Analysis under the Malaysian Penal Code', 2016 The Law Review 59. 
cease or prevent the infringement. ${ }^{17}$ However, if the offender does not cease or is not prevented from committing the infringement, the defender is permitted to kill the offender without any criminally liable repercussions. The majority of Muslim jurists do not justify the infliction of death simply by virtue of the fact that the deceased was in seclusion with a woman unless the fact of the commission of unlawful sexual intercourse has been established. Hence, it is possible to infer that the defense of the chastity of a woman differs from other types of private defense under Shariah as it requires the application of the lowest possible degree of force, avoiding the infliction of death upon the assailant. ${ }^{18}$

In analysing the defense of the chastity of a woman through the prism of different schools of Muslim jurists, it needs to be stated that the Shafie school claims that a man has an obligation to defend the chastity of a woman even if she is not under the apprehension of grievous bodily harm or death at the hands of the assailant. Moreover, there is consensus among Muslim scholars that it is incumbent upon a Muslim woman to defend herself and is allowed to kill the assailant in the course of defense without any criminal liability. ${ }^{19}$ In the meantime, Hanbali jurists distinguish two conditions of unlawful sexual intercourse to establish whether the consent to sexual intercourse was given or whether the sexual intercourse took place without the woman's consent. If the woman was engaged in a non-consensual act and the assailant was killed, the defender will not be liable for any punishment. However, in the case where a woman was a consenting party to the unlawful sexual intercourse and the assailant was killed, the defender shall be liable for retaliation (qisas). ${ }^{20}$

17 M. S El-Awa. 1981. Punishment in Islamic Law (American Trust Publications), 87.

18 N. Culson, 2011. A History Islamic Law (Aldine Transaction), 26.

19 Abd Allah Suleiman Al ajlan, 'Self-Defense and Provisions in Islamic Jurisprudence', (2010) 46 Justice Magazine (Arabic) (Author's translator) 157.

20 T Mahmood, 'Criminal law in Islam and the Muslim World: A Comparative Perspective’ (1996) 2 Institute of Objective Studies 16. 


\section{THE CONDITIONS FOR THE EXERCISE OF THE RIGHT OF PRIVATE DEFENSE}

This part discusses four conditions: the aggression must be unlawful; the aggression must be real or about to happen; the contravened should ward off any aggression with reasonable force; the aggression must be in progress.

\section{The Aggression Should be Unlawful}

The contravened shall be in a state of self-defense only when the aggression is unlawful as such unlawful aggression legitimates the right of self-defense to the contravened. ${ }^{21}$ Almighty Allah says "So whoever has assaulted you, then assault him in the same way that he has assaulted you". 22

The lawful action should not be warded off. This includes actions to retrieve a right, perform a duty and perform chastisement by the owner of this right such as a guardian, judge, enjoiner of good, teacher, parent, husband or any person who has the right of chastisement. However, if their actions exceed the legal limit, it shall be deemed a transgression and should be reconciled either by retaliation, compensation or value. In such cases, the person shall have the right to ward off such excess as it is regarded to be aggression. ${ }^{23}$

\section{The Aggression Must be Real or about to Happen}

The case of self-defense shall not be established unless;

a) The aggression actually happened - the aggressor initiated beating the victim, took his property or destroyed such, or tried to attack his wife, etc.

21 Abdul Qadir Audah, 2009. Islamic Criminal Legislation Compared to Positive Law (DAR Al-Kitab) (Arabic) (Author's Translation) Ch. 1 478480.

22 Holy Quran, Surah Al-Baqarah, V: 194.

23 Muwaffaq Al-Din Abd Allah Ibn Ahmed Ibn Qudamah, 1997. Al-Mughni (Dar Alam Alkutob Publishing,) (Arabic) (Author's Translation) ch 12 526528. 
b) The aggression was likely to happen and was not initiated-for example, the aggressor headed towards the victim taking up a weapon or aiming a gun or any other weapon at the victim and the victim was certain that the aggressor was serious and would attack him if he does not ward him off.

In both cases the victim shall be acting in self-defense and has the right to ward off the aggressor by reasonable means. In a case where the aggression is not established or is not likely to happen - for example, it was merely a threat or menace - the victim shall not be deemed to be in a position where self-defense may be exercised, as the delayed aggression does not need warding off due to the lack of danger. In this case, the aggression should be warded off by a suitable means such as resorting it to the general authorities, public or taking precautions to prevent such aggression or even running away. ${ }^{24}$

All actions committed by the abovementioned shall not consider an act of aggression if they do not transgress the lawful rights of the victim. Anyone performing his right shall not be regarded as an aggressor nor shall his actions be regarded as aggression.

\section{The Victim Should Ward off Any Aggression with Reasonable Force or Means}

The jurists' consensus is that the victim is entitled to ward off aggression by the lightest and least harmful means and should not resort to the strongest force when such means are available. ${ }^{25}$ In the case where he could ward off the aggressor verbally, remind the aggressor with Allah or seek help from the public or authorities, he should not beat the aggressor. The basic principle in Shariah is also to protect the aggressor's interest, for example, if the victim is able to ward off the aggressor's violent act by using his hand, he should not resort to a lash or other imminent

24 Mohammed Arafa Al-Doski and Ahmed Al-Darder Al-Adawe (ed), Hshiat Al-Doski on Al-Sharh Al-Kabir (DAR Al-Fqer) (Arabic) (Author's Translation) nd. ch 4357.

25 Abd Allah Suleiman Al ajlan, 'Self-Defense and Provisions in Islamic Jurisprudence', (2010) 46 Justice Magazine (Arabic) (Author's translator) ch 12 531-533. 
weapons; if he is able to ward him off using a lash, he should not use a stick or sword; if he is able to do such with a stick, he should not use a revolver; and if he is able to ward him off by cutting off a limb, he should not put the aggressor to death. It legitimates retaliation with a suitable punishment to ward off such aggression. There is no necessity to ward it off using the severe means if it can be warded off by the lightest means and it is thus prohibited to ward off aggression by using the deadly means first. ${ }^{26}$ The victim shall be liable for any damage in body or any minor damage and either retaliation or blood money shall apply if he warded off aggression using the strongest means instead of the lightest. In the case of unlawful self-defense, the contravened shall be accountable. ${ }^{27}$ In the case where the victim could find no other way to defend but the most forceful, he has the right to ward off using the strongest means; for example, if he feels that he will be killed by the aggressor, he is entitled to kill or amputate a limb and shall not pay compensation because he did so to ward off the aggressor. ${ }^{28}$

In the case where the defender could not judge how much force was required in self-defense or found it difficult to do so because the fighting had begun, then the grading shall not be considered, as if he did so, it shall result in his getting murdered. ${ }^{29}$ The same shall apply in a case where the aggressor had a stick and the victim only had a weapon; he is entitled to use the weapon and shall not be asked the reason for not using a stick. $^{30}$

With regards to warding off aggression using reasonable forceeither by words, beating, cutting or amputating or killing - the legal measure of force cannot be adequately estimated as the circumstances and facts surrounding the case may differ with regard to time, place,

26 Mohammad Ameen Ibn Omar Ibn Abdeen, 2013. Hashyat Ibn Abdeen (Dar Alam Alkutob Publishing, Riyadh) (Arabic) (Author's Translation) ch 6 546.

27 Fakhr Al-Din Uthman Ibn Ali Al-Zayla'I, 1898. Tabyyn Alhquq (Prince Publcation Press1th Cairo) (Arabic) (Author's Translation) ch 6111. Ala Al-Din Ibn Abu Bakr Ibn Musod Al Kasany, 2003. Buda Al Suna (Dar Al-Kotob Al-ilmiyah second published Beirut) (Arabic) (Author's Translation) ch 793.

29 Mohammed Ibn Ahmed Ibn Humza Ibn Shihab Al-Din Al Ramly Al Munofy, 2003. Nihyt Al Mohtaj (Dar Al-Kotob Al-ilmiyah, Second published Beirut) (Arabic) (Author's Translation) ch 827. 
persons and the means used in aggression; thus, the defense should be equal to the aggression if possible. However, where such estimation is required, it is grounded in logic, reason and proof. ${ }^{31}$ In Bazazi Fatwas, it is provided:

“... if he headed towards him taking up his sword at night or aiming his arrow and the defender be sure he wants to kill him, it is lawful for the defender to initiate fighting against him but, if the defender felt otherwise, it is forbidden to kill the aggressor, so here the defender's conduct depends more on the doubt". ${ }^{32}$

\section{The Aggression Must be in Progress}

The state of self-defense shall not be established unless the aggression is in progress. Lawful self-defense is deemed to start and end with the aggression and no defense shall be considered prior to or after the aggression. No legal self-defense shall be established, for example, in cases where the aggressor ceased beating, dropped his weapon or ran away, abandoned the stolen property or was warded off through another reason, for example, he fell into water or fire, his leg was broken or a wall or large hole came between them. If the contravened performs any action, it shall not be lawful and he shall be liable to retaliation or blood money for such action.

Where self-defense has been successfully used to prevent aggression and ward off damages, further self-defense shall be considered an act of aggression and a form of revenge. The ruler, not by the individual, shall carry out any penalties ${ }^{33}$ as individuals have no authority to retrieve their rights by themselves. Where aggression has occurred, the victim should raise it with the ruler to regain his right. The aggressor has been protected

31 M. S El-Awa. 1981. Punishment in Islamic Law (American Trust Publications), Ch. 1486.

32 Hafyz Al-Din Mohammad Ibn Shihab Al Bazaz Al Kardary, 1893. Fatawa Al Bazaz (Prince Publcation second published Cairo.) (Arabic) (Author's Translation) ch 6433 .

33 Ali Ibn Mohammed Ibn Habib Al Mawardy, 1989. Al Ahkam Al Sultaniah (Dar Ibn Qutibah first published Kuwait) (Arabic) (Author's Translation) 51. 
in Shariah like anyone, the law of self-defense justifying using force against him being temporary and proportionate. ${ }^{34}$

\section{CONCLUSION}

With due consideration given to all necessary aspects, jurists unanimously agreed that defending oneself, one's property and one's honour is permissible and legitimate. Moreover, self-defense in protecting or defending property has certain requirements that must be fulfilled, in order to be regarded as a justified self-defense without being subject to bearing criminal liability. The justifications are that the aggression must be unlawful, that it must be real or likely to happen, that it should be warded off with reasonable force and means, and that it must be in active progress. Thus, the basic principles in the concept of Maqasid al-Shariah are to protect faith (aqidah), soul (life), injury to body (jasd), property ( $\mathrm{mal}$ ), honour and dignity (izah) are guaranteed. The exercise of private defense against the vulnerable aggressors such as minors and insane persons and in protection of the chastity of women shall be permissible and lawful provided that the one warding off the aggression is applying reasonable force or using necessary means without being excessive according to reasonable man standard test.

34 Mansoor Ibn Yousaf Al-Bahooti, 1983. Kashaf Al Quna (Alam al-Kutub, Beirut) (Arabic) (Author's Translation) ch 6154. 